\title{
Bioedusiana
}

Blology

Education

Department

Universitas Siliwang

http://jurnal.unsil.ac.id/index.php/bioed

DOI: https://doi.org/10.37058/bioed.v6i2.3090

\section{Pengaruh Pembelajaran Problem Based Learning Berbasis Blended Learning terhadap Kemampuan Literasi Sains}

The Effect of Problem Based Learning Based on Blended Learning on Science Literacy Ability

\author{
Kurniawati $^{1 *}$, Nur Hidayah ${ }^{2}$ \\ 1,2 Program Studi Pendidikan Biologi, Fakultas Tarbiyah dan Keguruan, Universitas Islam Negeri Raden \\ Intan, Jalan Letkol. H. Endro Suratmin, Sukarame, Bandar Lampung, Lampung 35131, Indonesia
}

\begin{abstract}
Abstrak
Keterampilan pada pembelajaran sains di Sekolah Menengah Pertama (SMP) yang penting dalam pembelajaran IPA salah satunya yakni keterampilan literasi sains. Keterampilan literasi sains bertujuan untuk mengaplikasikan sains dengan baik dan benar. Keterampilan literasi sains peserta didik masih tergolong rendah dilihat dari ketercapaian per indikator literasi sains pada dimensi konten, proses dan konteks nilai rata-rata termasuk dalam kategori sangat kurang sekali yaitu 41,25 sehingga dibutuhkan pembelajaran yang mampu membantu peserta didik untuk melatih keterampilan literasi sains peserta didik. Tujuan dilakukannya penelitian yaitu melihat pengaruh pembelajaran Problem Based Learning berbasis Blended Learning terhadap kemampuan literasi sains peserta didik pada materi pencemaran lingkungan. Populasi penelitian seluruh peserta didik kelas VII di SMP Negeri 20 Bandar Lampung. Teknik pengambilan sampel acak peneliti mencampur subjek-subjek pada populasi sehingga semua subjek dianggap sama. Jenis penelitian yang digunakan adalah penelitian kuantitatif dengan metode Quasy Experimental. Subjek pada penelitian ini yaitu kelas eksperimen dan kelas kontrol dengan jumlah 62 peserta didik. Desain penelitian menggunakan desain Posttest Only Control Group Design bahwa kelompok kontrol dan sampel dipilih secara random tes akhir berupa posttest. Instrumen pada penelitian berupa tes literasi sains berjumlah 10 soal. Hasil analisis data yang diperoleh hasil perhitungan uji- $t$ dua sampel yang tidak berkorelasi dan taraf signifikan $5 \%$ diperoleh nilai $p-$ value $=$ 0,000 . Artinya nilai $p-$ value $=0,000<\alpha=0,05$, sehingga $H_{0}$ ditolak dan $H_{1}$ diterima. Dengan demikian perlakuan terhadap kelas eksperimen dan kelas kontrol dapat mengukur sejauh mana peningkatan kemampuan literasi sains yang dihasilkan setelah perlakuan. Hasil penelitian diperoleh kesimpulan bahwa adanya pengaruh kemampuan literasi sains peserta didik menggunakan pembelajaran Problem Based Learning berbasis Blended Learning.
\end{abstract}

Kata kunci: Blended Learning; Literasi Sains; Problem Based Learning

\begin{abstract}
Skills in science learning in Junior High Schools (SMP) that are important in learning science, one of which is scientific literacy skills. Scientific literacy skills aim to apply science properly and correctly. The scientific literacy skills of students are still relatively low, judging from the achievement of the scientific literacy indicators on the dimensions of content, proses and context, the average score is included in the very poor category, namely 41.25 so that learning is needed that can help students train students' science literacy skills. The purpose of the research is to see the effect of problem-based learning on Blended Learning on the scientific literacy skills of student on environmental pollution material. The study population was all seventh-grade students at SMP Negeri 20 Bandar Lampung. The researcher's sampling technique mixed subjects in the population so that all subjects were considered the same. The type of research used is quantitative research with Quasi Experimental method. The subjects in this study were the experimental class and the control class with a total of 62 students. The research design used the posttest only control group design, where the control group and the sample were randomly selected. The final test was in the form of a posttest. The instrument in the study was a science literacy test with 10 questions. The results of the analysis of the date obtained from the t-test calculations of two uncorrelated sample and a significant level of $5 \%$ obtained $p-$ value $=0,000$. This means that the $p-$ value $=0,000<\alpha=0,05$, so HO rejected and $\mathrm{H} 1$ is accepted. Thus, the treatment of the experimental class and the control class can measure the extent to which the increase in scientific literacy skills resulted after the treatment. The results of the study concluded that there was an influence on students' scientific literacy skills using Problem Based Learning on Blended Learning.
\end{abstract}

Keywords: Blended Learning; Science Literacy; Problem Based Learning 
Article History

Received: May 30 ${ }^{\text {th }}, 2021$; Accepted: November 30 ${ }^{\text {th }}, 2021$; Published: December $31^{\text {st }}, 2021$

Corresponding Author*

Kurniawati, Program Studi Pendidikan Biologi, Fakultas Tarbiyah dan Keguruan, Universitas Islam Negeri Raden Intan, E-mail: niabiologi2912@gmail.com

(C) 2021 Bioedusiana. This is an open access article under the CC BY-SA 4.0 license

(https://creativecommons.org/licenses/by-sa/4.0/)

\section{PENDAHULUAN}

Teknologi dan pengetahuan berkembang pesat sehingga peserta didik dituntut untuk dapat mengikuti perkembangan zaman. peserta didik diharapkan dapat berpikir secara logis dan kreatif, serta memiliki kemampuan secara mandiri dalam memecahkan masalah dan mengambil keputusan. Pemecahan masalah sering diterapkan pada kegiatan pembelajaran bidang Ilmu Pengetahuan Alam (IPA). Tujuan dari pemecahan masalah yakni membantu dalam menguasai pengetahuan berkaitan dengan pembelajaran sains, sehingga peserta didik memiliki kemampuan untuk memecahkan dalam kehidupan sehari-hari (Ismail et al., 2016). Pembelajaran sains yaitu proses pembelajaran meliputi kegiatan yang dirancang secara teratur untuk dapat menyelidiki fenomena alam dan dapat menghasilkan produk ilmiah, proses ilmiah serta sikap ilmiah (Taqiyyah et al., 2017). Pendidikan sains memiliki peranan utama yaitu dapat mengimplementasikan masyarakat yang berliterasi sains (Rusdi et al., 2017).

Literasi sains menurut penjelasan dalam PISA dapat diartikan secara kapasitas memerlukan suatu pengetahuan ilmiah, mengidentifikasi pertanyaan, dan mengambil kesimpulan bersumber sesuai fakta sebagai wujud mempelajari alam semesta beserta perubahan yang terjadi disebabkan karena aktivitas ulah perbuatan manusia (Bahrul Hayat, Suhendra Yusuf, 2015). Literasi sains merupakan kualitas peserta didik dalam memahami permasalahan sehari-hari dikaitkan dengan materi yang telah dipelajari, sehingga mampu bersikap positif dan kepekaan yang baik mengenai diri dan lingkungan (Wilujeng, 2016). Hampir semua peserta didik pasti memiliki kemampuan literasi sains, karena hal tersebut memiliki kaitannya antara peserta didik yang mampu memahami permasalahan yang sangat bergantung dengan pengetahuan dan teknologi (Haerani et al., 2020).

Kemampuan dalam pemahaman konsep, menguasai, menjelaskan, mengkomunikasikan, dan menerapkan sains pada kehidupan sehari-hari merupakan kemampuan literasi sains yang seharusnya dimiliki peserta didik, sehingga peserta didik memiliki sikap positif serta kepekaan terhadap diri dan lingkungan sekitar (Wilujeng, 2016). Dunia pendidikan dihadapkan permasalahan kemampuan literasi sains peserta didik tergolong rendah oleh sebab itu masalah tersebut harus segera diatasi (Taofiq et al., 2018). Masalah yang dimaksud bahwa kemampuan literasi sains peserta didik yang masih rendah yang ada di lingkungan dimana belum menunjukkan literasi sains yang sesuai dengan harapan, seperti yang ditunjukkan oleh hasil penilaian PISA (OECD, 2009-2013, 2015). Peringkat Indonesia di PISA sesuai dengan hasil 
pemetaan Tahun 2009,2012, dan tahun 2015 adalah urutan 57,64, dan 64 dari keseluruhan 65,65, dan 72 negara mendapat nilai 383, 382, dan 403. (Nugraha et al., 2017).

Kemampuan literasi sains peserta didik tergolong rendah dapat disebabkan oleh beberapa faktor baik secara internal ataupun eksternal. Keadaan iklim dan lingkungan belajar di sekolah dapat mempengaruhi variasi skor literasi sains peserta didik. Demikian pula dengan keadaan infrastruktur sekolah, sumber daya manusia, dan tipe organisasi manajemen sekolah, hal tersebut sangat signifikan pengaruhnya terhadap prestasi literasi sains peserta didik. Kurnia mengungkapkan bahwa rendahnya literasi mengenai sains pada peserta didik di Indonesia berkaitan erat dengan adanya perbedaan realita lapangan dengan standar PISA meliputi Kimia, Fisika, dan Biologi (Bahrul Hayat, 2006).

Sub bab pada materi bidang studi IPA salah satunya yaitu kaitannya erat dengan literasi sains yaitu pencemaran lingkungan. Materi ini tercantum dalam KD 3.8 Menganalisa pada halhal yang terjadi dengan pencemaran lingkungan serta dampaknya pada ekosistem dan KD 4.8 hal ini tertulis terkait gagasan penyelesaian dari permasalahan di lingkungan sekitarnya berdasarkan dari hasil observasi. Materi pencemaran lingkungan memuat permasalahan yang terjadi di lingkungan sekitar, adapun jenis-jenis dari pencemaran lingkungan yaitu pencemaran air, udara, dan tanah. Dampaknya untuk ekosistem dengan begitu melibatkan peserta didik agar dapat mengidentifikasi terjadinya lingkungan yang tercemar, upaya penanggulangan pencemaran lingkungan, menyajikan hasil analisis data pengamatan proses terjadinya pencemaran air, udara dan tanah serta analisis data mengenai pencemaran terhadap ekosistem dan upaya penanggulangannya.

Berdasarkan hasil wawancara pra penelitian yang telah dilakukan di SMP Negeri 20 Bandar Lampung dengan beberapa guru mata pelajaran IPA materi biologi kelas VII mengenai permasalahan yang terjadi bahwa perangkat dan model untuk pembelajaran yang digunakan di sekolah belum mencakup unsur literasi sains sehingga dalam proses pembelajaran terindikasi belum mencapai hasil yang memuaskan. Seperti yang diketahui bahwa dengan keharusan kurikulum 2013 yang notabenenya menekankan pada keterampilan High Order Thingking Skill (HOTS) dan literasi, hal ini menunjukkan bahwa keterampilan literasi sains peserta didik perlu diukur dan ditingkatkan. Hasil pra penelitian kemampuan literasi sains peserta didik menggunakan lima indikator literasi sains yaitu memahami fenomena, mengidentifikasi permasalahan ilmiah, menjelaskan fenomena ilmiah, menggunakan bahan bukti ilmiah, dan internalisasi bidang aplikasi sains dalam seting personal, sosial dan global dengan menggunakan 15 butir soal didapatkan hasil bahwa kemampuan literasi sains peserta didik dikategorikan sangat kurang, berdasarkan hasil analisis jawaban per butir soal nilai persentase dibawah $60 \%$ dengan demikian perlu strategi pembelajaran yang dapat membantu peserta didik untuk melatih meningkatkan kemampuan literasi sains sebagai pendukung dalam kegiatan pembelajaran 
dengan mengimplementasikan model pembelajaran yang mempunyai karakteristik pendekatan ilmiah salah satunya yakni model Problem Based Learning.

Kemampuan literasi sains suatu kemampuan yang digunakan untuk menginterpretasikan sains, yang mampu memberikan peluang sebagai solusi terhadap permasalahan yang dihadapi dalam kehidupan sehari-hari. Menurut pendapat G Rahayu bahwa pentingnya kemampuan literasi sains sehingga perlu dipersiapkan pada peserta didik yang berfungi untuk menyelesaikan permasalahan dalam kehidupan sehari-hari. Setiap individu perlu menguasai kemampuan literasi sains, hal ini berkaitan dengan bagaimana seseorang dapat memahami permasalahan di lingkungan hidup dan masalah-masalah lain yang dihadapi oleh masyarakat modern yang sangat bergantung pada ilmu pengetahuan dan teknologi (Haerani et al., 2020).

Model pembelajaran Problem Based Learning ini, peserta didik dapat dilakukan secara individu dan berkelompok kolaboratif untuk mengetahui kebutuhan pada proses pemecahan masalah. Masalah yang dihadirkan dalam pembelajaran menggunakan model Problem Based Learning merupakan permasalahan yang ada kaitannya dalam kehidupan sehari-hari, karena hal tersebut model pembelajaran Problem Based Learning tepat diterapkan pada pembelajaran biologi (Aulia et al., 2019). Pembelajaran Problem Based Learning dipadukan dengan metode Blended Learning memberi dorongan peserta didik untuk mengaplikasikannya pada kehidupan berdasarkan kemajuan dari teknologi, informasi dan komunikasi yang ada, dengan begitu peserta didik mampu memecahkan permasalahan di lingkungan sekitarnya. Beberapa penelitian yang telah dilakukan diketahui bahwa penerapan model pembelajaran Blended Learning dalam kegiatan pembelajaran di sekolah menunjukkan peningkatan positif terhadap kemampuan literasi sains peserta didik. Di SMP 2 Surakarta penerapan model pembelajaran Blended Learning berbantuan media Moodle menunjukkan bahwa terdapat peningkatan kemampuan literasi sains peserta didik (Lestari, 2020).

Hasil penelitian oleh Defrizal Hamka dan Noverta Effendi yaitu media pembelajaran Blended Learning berbasis Edmodo, menggunakan kelas online bisa membantu atau menjadi sesuatu yang dapat menggantikan pada kelas konvensional (Hamka \& Effendi, 2019). Selanjutnya Penelitian selanjutnya tentang tahap self-paced learning pada kelas Blended Learning memungkinkan peserta didik memiliki kemandirian tinggi, mampu mengontrol diri, memiliki rasa tanggung jawab dan berperilaku disiplin. Penelitian berikutnya membuktikan bahwa Guided Inquiry-Blended Learning berpengaruh terhadap peningkatan literasi sains, yaitu dapat meningkatkan kemampuan memvalidasi literatur, mendesain penelitian ilmiah, dan kemampuan dasar statistik (Adi et al., 2017).

Pembelajaran menggunakan metode Blended Learning mempunyai kelebihan yaitu memudahkan peserta didik dalam belajar memfasilitasi peserta didik dengan memanfaatkan beberapa platform seperti aplikasi WhatsApp, Google Classroom, dan Zoom meeting dipadukan 
menggunakan model pembelajaran yaitu Problem Based Learning. Triyanto et al., (2016) menyatakan Blended-Problem Based Learning dapat diterapkan sebagai model pembelajaran yang mendorong aktivitas positif siswa dalam belajar. Hal tersebut sesuai menurut pendapat Hernandez bahwa model pembelajaran menggunakan Blended Learning merupakan salah satu model pembelajaran yang sesuai dengan proporsi peserta didik (Nanclares, 2016). Sedangkan menurut pendapat Crawford model pembelajaran menggunakan Blended Learning dapat menjadikan peserta didik lebih bereksplorasi dan dapat meningkatkan daya tangkap peserta didik (Crawford, 2017). Berdasarkan pendapat Irmita literasi sains dapat digunakan melalui pembelajaran yang memiliki kaitannya dengan teknologi (Fuadi, 2020). Berdasarkan permasalahan yang ada, peneliti mengharapkan suatu model pembelajaran yang dapat meningkatkan literasi sains. Peneliti akan menerapkan pembelajaran Problem Based Learning berbasis Blended Learning pada tingkat sekolah menengah pertama. Tujuan dari penelitian ini adalah upaya peningkatan literasi sains peserta didik menggunakan pembelajaran Problem Based Learning berbasis Blended Learning.

\section{METODE}

Jenis penelitian yang digunakan adalah kuantitatif dan menggunakan metode Quasy Experiment dengan desain penelitian The Posttest Only Control Group Desaign. Penelitian ini dilakukan di Bandar lampung tingkat Sekolah Menengah Pertama, yaitu di SMP Negeri 20 Bandar Lampung, Provinsi Lampung. Populasi pada penelitian ini adalah peserta didik kelas VII semester genap tahun 2020/2021. Sampel pada penelitian ini adalah kelas VII G dan VII H. Sebagai kelas eksperimen VII G dan sebagai kelas kontrol kelas VII H. Teknik pengambilan sampel pada penelitian ini menggunakan Cluster Random Sampling. Adapun desain penelitian tercantum pada Tabel 1. Berikut desain penelitian metode Quasy Experiment:

Tabel 1. Desain Penelitian

\begin{tabular}{ccc}
\hline Kelompok & Perlakuan & Posttest \\
\hline Eksperimen & $\mathrm{X} 1$ & $\mathrm{Q} 1$ \\
\hline Kontrol & $\mathrm{X} 2$ & $\mathrm{Q} 2$ \\
\hline
\end{tabular}

Keterangan:

$Q 1=$ Posttest pada kelas eksperimen

$Q 2=$ Posttest pada kelas kontrol

$X 1=$ Perlakuan menggunakan model Problem Based Learning berbasis Blended Learning

$X 2=$ Perlakuan menggunakan Model Direct Instruction . 
Prosedur penelitian ini terdiri dari tahap perencanaan, pelaksanaan dan akhir. Tahap perencanaan terdiri dari pembuatan Rencana Pelaksanaan Pembelajaran (RPP), silabus, soal essay literasi sains materi pencemaran lingkungan, dan Lembar Kerja Peserta Didik (LKPD). Tahap pelaksanaan menerapkan pembelajaran Problem Based Learning berbasis Blended Learning untuk kelas eksperimen sedangkan kelas kontrol menggunakan pembelajaran direct instruction. Pada tahap akhir dilakukan analisis data penelitian, pembahasan dan kesimpulan. Berikut kisikisi tes kemampuan literasi sains yang terdiri dari lima indikator yang akan digunakan dipertegas pada Tabel 2 sebagai berikut:

Tabel 2. Kisi-kisi Soal Literasi Sains

\begin{tabular}{llc}
\hline \multicolumn{1}{c}{ Dimensi Literasi Sains } & \multicolumn{1}{c}{ Indikator Literasi Sains } & Nomor Butir Soal \\
\hline Konten & $\begin{array}{l}\text { Memahami fenomena (memahami konsep } \\
\text { dengan benar) }\end{array}$ & 1 \\
\hline Proses & $\begin{array}{l}\text { Mengidentifikasi permasalahan ilmiah } \\
\text { (berkaitan dengan permasalahan yang dapat } \\
\text { diselidiki secara ilmiah) }\end{array}$ & $2,3,4$ \\
& $\begin{array}{l}\text { Menjelaskan fenomena secara ilmiah } \\
\text { (mendeskripsikan atau menafsirkan fenomena } \\
\text { ilmiah dan prediksi perubahan) }\end{array}$ & 5,6 \\
& $\begin{array}{l}\text { Menggunakan bahan bukti ilmiah } \\
\text { (mengidentifikasi asumsi, bukti, dan alasan } \\
\text { balik kesimpulan) }\end{array}$ & \\
\hline Kemecahkan permasalahan secara ilmiah \\
bidang aplikasi sains dalam seting personal, \\
sosial dan global (menerapkan konsep sains \\
secara personal, sosial, dan global)
\end{tabular}

\section{HASIL DAN PEMBAHASAN}

HASIL

Penelitian telah dilaksanakan di SMP Negeri 20 Bandar Lampung dengan sampel penelitian ialah peserta didik kelas VII semester genap, tentang pengaruh model pembelajaran Problem Based Learning berbasis Blended Learning terhadap literasi sains peserta didik pada mata pelajaran biologi tentang pencemaran lingkungan. Penelitian ini menggunakan dua kelas yaitu kelas VII G sebagai kelas eksperimen dengan mengaplikasikan model pembelajaran Problem Based Learning berbasis Blended Learning dan kelas VII H sebagai kelas kontrol menggunakan direct instruction.

Model pembelajaran yang digunakan bertujuan untuk mengetahui kemampuan literasi sains peserta didik. Pengukuran dilaksanakan pada tahap akhir proses pembelajaran berupa soal posttest yang diberikan pada kelas eksperimen dan kelas kontrol. Setelah dilaksanakan tes kemampuan literasi sains hasil rekapitulasi dari kedua kelas secara keseluruhan berdasarkan perhitungan per indikator literasi sains. Adapun hasil penelitian tes kemampuan literasi sains pada Tabel 3. Berikut adalah hasil penelitian pada kelas eksperimen dan kontrol pada tes kemampuan literasi sains: 
Tabel 3. Hasil Penelitian Tes Kemampuan Literasi Sains

\begin{tabular}{|c|c|c|c|c|c|c|c|}
\hline \multirow[t]{2}{*}{ Kelompok } & \multirow{2}{*}{$\mathbf{X}_{\max }$} & \multirow[t]{2}{*}{$\mathbf{X}_{\min }$} & \multicolumn{3}{|c|}{ Ukuran Terdensi Sentral } & \multicolumn{2}{|c|}{$\begin{array}{c}\text { Ukuran Variansi } \\
\text { Kelompok }\end{array}$} \\
\hline & & & $\overline{\mathbf{x}}$ & $\mathbf{M}_{\mathbf{o}}$ & $\mathbf{M}_{\mathbf{e}}$ & $\mathbf{R}$ & Sd \\
\hline Eksperimen & 100,00 & 67,50 & 83,75 & 82,50 & 82,50 & 32,50 & 8,49 \\
\hline Kontrol & 92,50 & 65,00 & 75,87 & 80,00 & 75,00 & 27,50 & 7,55 \\
\hline
\end{tabular}

Berdasarkan Tabel 3, terlihat bahwa kelas eksperimen yang menerapkan model pembelajaran Problem Based Learning berbasis Blended Learning memiliki hasil posttest kemampuan literasi sains yang lebih baik dari kelas kontrol. Hal tersebut dapat dilihat dari nilai rata-rata $(\bar{X})$ sebesar 83,75 , nilai yang sering muncul $\left(M_{o}\right)$ sebesar 82,50 dan memiliki nilai simpangan baku (Sd) yang kecil yaitu 8,49. Hasil range (R) pada kelas eksperimen yang menerapkan model pembelajaran Problem Based Learning berbasis Blended Learning tergolong cukup besar yaitu sebesar 32,50. Hasil tersebut menunjukkan bahwa terdapat perbedaan yang cukup signifikan antara nilai rata-rata nilai maksimal dan rata-rata nilai minimum.

Adapun persentase hasil posttest kemampuan literasi sains tercantum pada Tabel 4. Berikut persentase hasil posttest kemampuan literasi sains peserta didik pada kelompok kelas eksperimen dan kelas kontrol.

Tabel 4. Persentase Hasil Posttest Kemampuan Literasi Sains

\begin{tabular}{clcc}
\hline \multirow{2}{*}{ No. } & \multirow{2}{*}{ Memahami fenomena } & \multicolumn{2}{c}{ Persentase Ketercapaian } \\
\cline { 3 - 4 } & & Kelas Eksperimen & Kelas Kontrol \\
\hline 1 & Memahami fenomena & $86,29 \%$ & $75,81 \%$ \\
\hline 2 & Mengidentifikasi permasalahan ilmiah & $83,60 \%$ & $75,54 \%$ \\
\hline 4 & Menjelaskan fenomena secara ilmiah & $85,08 \%$ & $67,74 \%$ \\
\hline 5 & Menggunakan bahan bukti ilmiah & $74,19 \%$ & $87,90 \%$ \\
\hline & Memecahkan permasalahan secara ilmiah & $85,48 \%$ & $77,15 \%$ \\
\hline
\end{tabular}

Berdasarkan Tabel 4, dapat dilihat bahwa persentase ketercapaian indikator literasi sains yang pertama yaitu Memahami fenomena pada kelas eksperimen sebesar 86,29\% dan kelas kontrol sebesar 75,81\%. Kemudian persentase ketercapaian indikator literasi sains yang kedua yaitu mengidentifikasi permasalahan ilmiah pada kelas eksperimen sebesar 83,60\% dan kelas kontrol sebesar $75,54 \%$. Selanjutnya persentase ketercapaian indikator literasi sains yang ketiga yaitu menjelaskan fenomena secara ilmiah pada kelas eksperimen sebesar 85,08\% dan kelas kontrol sebesar $67,74 \%$. Berikutnya persentase ketercapaian indikator literasi sains yang pertama yaitu menggunakan bahan bukti ilmiah pada kelas eksperimen sebesar 74,19\% dan kelas kontrol sebesar $87,90 \%$. Terakhir persentase ketercapaian indikator literasi sains yang 
pertama yaitu memecahkan permasalahan secara ilmiah pada kelas eksperimen sebesar $85,48 \%$ dan kelas kontrol sebesar 77,15\%. Bahwa rata-rata persentase ketercapaian indikator literasi sains pada kelas eksperimen sebesar $82,93 \%$ dan kelas kontrol sebesar 76,83\%. Hal ini dapat dilihat pada bentuk diagram gambar 1 dibawah ini:

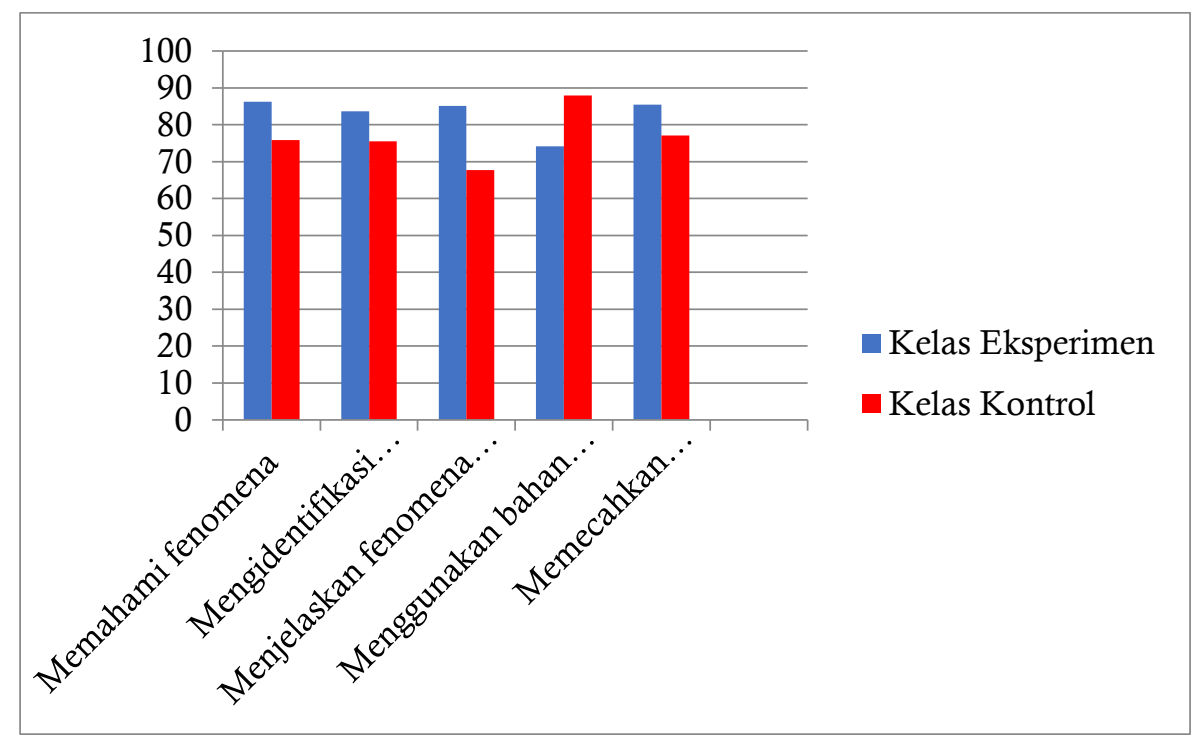

Gambar 1. Persentase Ketercapaian Indikator Literasi Sains Kelas Eksperimen dan Kelas Kontrol

Data tes kemampuan literasi sains dari kelas eksperimen dan kontrol dianalisis menggunakan uji prasyarat dan uji hipotesis. Langkah pertama akan dilakukan analisis data yang berupa uji normalitas pada hasil tes kemampuan literasi sains peserta didik. Adapun hasil perhitungan uji normalitas kemampuan literasi sains tercantum pada Tabel 5. Berikut adalah hasil perhitungan uji normalitas kemampuan literasi sains:

Tabel 5. Hasil Perhitungan Uji Normalitas Kemampuan Literasi Sains

\begin{tabular}{cccc}
\hline Kelompok & $\boldsymbol{p}-$ Value & Signifikansi & Keputusan \\
\hline Eksperimen & 0,200 & 0,05 & Teristribusi Normal \\
\hline Kontrol & 0,200 & 0,05 & Teristribusi Normal \\
\hline
\end{tabular}

Berdasarkan Tabel 5, diperoleh hasil dengan taraf signifikansi $a=0,05$ dan $p-$ Value $>\alpha$ yaitu untuk kelas eksperimen 0,200>0,05 dan kelas kontrol 0,200>0,05. dapat ditarik kesimpulan bahwa data tersebut berdistribusi normal.

Langkah selanjutnya akan dilakukan analisis data yang berupa uji homogenitas. Adapun hasil perhitungan uji homogenitas kemampuan literasi sains tercantum pada Tabel 6 sebagai berikut: 
Tabel 6. Hasil Perhitungan Uji Homogenitas Kemampuan Literasi Sains

\begin{tabular}{cc}
\hline Statistik & Kemampuan Literasi Sains \\
\hline $\boldsymbol{p}-$ Value & 0,725 \\
\hline Homogeneity & $p-$ Value $>0,05$ \\
\hline Kesimpulan & Homogen \\
\hline
\end{tabular}

Berdasarkan Tabel 6, terlihat bahwa - Value $=0,725>\alpha=0,05$. Dapat disimpulkan bahwa data tersebut homogen. Selanjutnya, karena populasi datanya terdistribusi normal dan homogen, maka dapat dilakukan uji hipotesis. Adapun hasil uji hipotesis tercantum pada Tabel 7. Uji hipotesis yang digunakan yaitu uji-t dua sampel yang tidak berkorelasi dan taraf signifikan $5 \%$ adalah sebagai berikut:

Tabel 7. Hasil Uji Hipotesis Uji-t

\begin{tabular}{|c|c|c|c|c|}
\hline \multicolumn{5}{|c|}{ Independent Samples Test } \\
\hline & & \multicolumn{3}{|c|}{ t-test for Equality of Means } \\
\hline & & $\mathrm{t}$ & $\mathrm{df}$ & Sig. (2-tailed) \\
\hline \multirow[t]{2}{*}{ Literasi Sains } & Equal variances assumed & 3,991 & 60 &, 000 \\
\hline & Equal variances not assumed & 3,991 & 59,205 &, 000 \\
\hline
\end{tabular}

Berdasarkan Tabel 7, hasil perhitungan uji-t yaitu nilai $p$-value $=0,000<\alpha=0,05$, sehingga $H_{0}$ tolak dan $H_{1}$ diterima. Sehingga dapat dilihat bahwa adanya pengaruh model pembelajaran Problem Based Learning berbasis Blended Learning pada kemampuan literasi sains peserta didik pada kelas eksperimen dengan kelas kontrol.

\section{PEMBAHASAN}

Kegiatan pembelajaran berlangsung selama tiga kali pertemuan pada kelas eksperimen menggunakan model pembelajaran Problem Based Learning berbasis Blended Learning sedangkan pada kelas kontrol menggunakan metode direct instruction. Pada kelas eksperimen model pembelajaran Problem Based Learning berbasis Blended Learning memberikan kesempatan peserta didik berperan aktif, menggunakan pemahaman yang lebih ilmiah, mengenal permasalahan yang berhubungan pada kehidupan sehari-hari sehingga pembelajaran yang berlangsung lebih menarik dan tidak membosankan, memicu minat belajar peserta didik. Sedangkan pada kelas kontrol menggunakan metode direct instruction. Proses kegiatan belajar dilaksanakan dengan cara pendidik menyampaikan materi melalui power point kemudian diarahkan untuk meringkas kembali hal penting mengenai materi yang telah disampaikan oleh pendidik.

Selanjutnya setelah kegiatan pembelajaran kedua kelas selesai pendidik memberikan soal tes akhir (posttest) bertujuan untuk mengetahui kemampuan literasi sains peserta didik, lalu mengolah data dan mendapatkan hasil yang akan peneliti jelaskan. Setelah selesai melakukan perhitungan dan pengolahan data tes akhir (posttest) mendapatkan hasil pada tabel 4 yaitu 
kemampuan literasi sains pada kelas eksperimen, nilai tertinggi $\left(X_{\text {maks }}\right) 100$, nilai terendah $\left(X_{\text {min }}\right)$ 67,50 dan nilai rata-rata 82,93. Sedangkan kemampuan literasi sains pada kelas kontrol nilai tertinggi $\left(X_{\text {maks }}\right) 92,50$, nilai terendah $\left(X_{\min }\right)$ 65,00 dan nilai rata-rata 76,83. Berdasarkan hasil tersebut dapat diketahui bahwa nilai ketercapaian kemampuan literasi sains peserta didik kelas eksperimen lebih tinggi dari pada kelompok kelas kontrol. Ketercapaian aspek sikap literasi sains peserta didik pada kelas eksperimen lebih tinggi daripada kelas kontrol hal tersebut tidak lepas dari pengaruh dari perlakuan yang diberikan berupa penerapan model pembelajaran Problem Based Learning pada kelas eksperimen (Wulandari \& Sholihin, 2015). Peneliti juga melakukan perhitungan ketercapaian nilai peserta didik per indikator literasi sains peserta didik, yaitu terdiri dari lima indikator; memahami fenomena, mengidentifikasi permasalahan ilmiah, menjelaskan fenomena secara ilmiah, menggunakan bahan bukti ilmiah, dan memecahkan permasalahan secara ilmiah.

Hasil perhitungan setiap indikator literasi sains pada Tabel 4 bahwa menunjukkan hasil, pada indikator literasi sains yang pertama yaitu memahami fenomena. Kelompok kelas eksperimen mencapai skor 86, 29\% termasuk dalam kriteria sangat baik, sedangkan pada kelas kontrol mencapai skor $75,81 \%$ termasuk dalam kriteria cukup. Ketercapaian yang berbeda ini disebabkan karena adanya perlakuan dalam proses pembelajaran, pada kelas eksperimen peserta didik mendapat kesempatan untuk melatih diri dalam kegiatan menganalisis suatu permasalahan menggunakan bantuan fishbone diagram oleh sebab itu dapat mengidentifikasi masalah lebih sistematis (Meylani et al., 2018). Indikator literasi sains yang pertama yaitu menjelaskan fenomena menggunakan model pembelajaran Problem Based Learning berbasis Blended Learning terdapat dalam sintaksnya tahap orientasi ialah dengan peserta didik diberi stimulus permasalahan melalui zoom meeting yang sering terjadi di kehidupan sehari-hari dengan menampilkan gambar tentang bencana alam salah satu dampak yang diakibatkan dari pencemaran lingkungan, kemudian peserta didik diminta untuk mengamati gambar tersebut, setelah mengamati pendidik mengarahkan peserta didik untuk memberikan pertanyaan dan tanggapan tentang permasalahan yang diamati. Tahap orientasi masalah untuk melatih kemampuan berpikir serta minat peserta didik dalam mengikuti proses belajar, yang merupakan tahap awal guna mengembangkan kemampuan literasi peserta didik pada tahap fungsional (Adiwiguna et al., 2019). Oleh karena itu, peserta didik lebih mudah dalam menjawab suatu persoalan dengan menggunakan penjelas sederhana. Sedangkan pada kelas kontrol proses pembelajaran tidak diberikan pengajaran yang melatih pendapat hanya menjawab pertanyaan sesuai dengan materi yang disajikan pendidik pada power point.

Indikator literasi sains yang kedua yaitu mengidentifikasi permasalahan secara ilmiah, kelompok kelas eksperimen mencapai skor $83,60 \%$ termasuk dalam kriteria baik, sedangkan pada kelas kontrol mencapai skor 75,54\% termasuk dalam kriteria cukup. Dimana dalam 
sintaksnya model pembelajaran Problem Based Learning berbasis Blended Learning yang mendukung pada indikator kedua ialah tahap mengorganisasi, kegiatan peserta didik untuk meneliti kemudian membangun pengetahuannya sendiri melalui diskusi bertujuan untuk mengidentifikasi permasalahan dan akibat yang ditimbulkan menggunakan bukti-bukti yang relevan. Selanjutnya pendidik membantu peserta didik mendefinisikan dan mengorganisasikan tugas belajar yang berhubungan dengan suatu permasalahan yang terdapat pada gambar yang ditampilkan pada saat pembelajaran berlangsung menggunakan zoom meeting. Ketercapaian yang berbeda ini disebabkan karena adanya perlakuan dalam proses pembelajaran, menggunakan teknik Blended Learning mendapatkan informasi tambahan berupa materi pendahuluan, video pembelajaran, dan gambar yang diberikan pendidik melalui schoology, peserta didik memperoleh materi pendalaman tersebut setelah pembelajaran berakhir sehingga peserta didik mampu belajar secara mandiri dimanapun dan kapanpun (Anggraeni et al., 2019). Sedangkan pada kelas kontrol peserta didik kegiatan pembelajarannya menggunakan direct instrunction pendidik menginstruksikan peserta didik untuk menyelesaikan permasalahan melalui pertanyaan sederhana.

Indikator literasi sains yang ketiga yaitu menjelaskan fenomena secara ilmiah, kelompok kelas eksperimen mencapai skor 85, 08\% termasuk dalam kriteria baik, sedangkan pada kelas kontrol mencapai skor $67,74 \%$ termasuk dalam kriteria cukup. Didalam sintaksnya model pembelajaran Problem Based Learning berbasis Blended Learning yang mendukung pada indikator ketiga pada tahap investigasi peserta didik secara mandiri maupun kelompok. Pendidik mendorong peserta didik untuk mengumpulkan informasi yang sesuai, dengan melaksanakan pengamatan untuk mendapatkan penjelasan dan pemecahan masalah utama terhadap fenomena yang telah diamati. Peningkatan keterampilan pemecahan masalah peserta didik disebabkan karena Blended Learning yang sudah memberikan banyak pengaruh positif terhadap hasil belajar terutama dalam kemampuan pemecahan masalah (Anggraini \& Syahbrudin, 2021). Ketercapaian yang berbeda ini disebabkan karena adanya perlakuan dalam proses pembelajaran, pada kelas eksperimen peserta didik mengamati permasalahan berdasarkan fenomena yang terjadi dalam kehidupan sehari-hari dengan cara mengamati dampak pencemaran air yang disebabkan limbah rumah tangga seperti detergen. Sedangkan pada kelas kontrol hanya mengamati gambar fenomena alam akibat dampak dari pencemaran lingkungan melalui power point.

Indikator literasi sains yang keempat yaitu menggunakan bahan bukti ilmiah kelompok kelas eksperimen mencapai skor 74,19\% termasuk dalam kriteria cukup, sedangkan pada kelas kontrol mencapai skor $87,90 \%$ termasuk dalam kriteria sangat baik. Didalam sintaknya model pembelajaran Problem Based Learning berbasis Blended Learning yang mendukung pada indikator ini pada tahap menganalisis proses pemecahan masalah. Peserta didik menganalisis 
permasalahan yang telah ditemukan diawal yang mana peserta didik mencari solusi berdasarkan fenomena yang terjadi pada kehidupan sehari-hari guna mengurangi permasalahan pada pencemaran udara dan tanah yang telah tersedia didalam LKPD. Selanjutnya salah satu peserta didik menjadi perwakilan untuk menyampaikan kepada teman-temannya. Berdasarkan penelitian yang dilakukan oleh Dwiyogo Pembelajaran berbasis Blended Learning mampu meningkatkan kemampuan pemecahan masalah peserta didik melalui video pembelajaran peserta didik dapat memvisualisasikan suatu fenomena berdasarkan video yang dilihat dibandingkan menggunakan pembelajaran konvensional (Suana et al., 2019). Sedangkan pada kelas kontrol pendidik hanya mengarahkan peserta didik untuk menganalisis permasalahan dengan merangkum materi yang telah disampaikan.

Indikator literasi sains yang kelima yaitu memecahkan permasalahan secara ilmiah, kelompok kelas eksperimen mencapai skor 85, 48\% termasuk dalam kriteria baik, sedangkan pada kelas kontrol mencapai skor $77,15 \%$ termasuk dalam kriteria baik. Didalam sintaksnya model pembelajaran Problem Based Learning berbasis Blended Learning yang mendukung pada indikator ini pada tahap evaluasi. Pendidik membantu peserta didik melakukan refleksi atau evaluasi terhadap penyelidikan yang telah dilakukan dan proses-proses yang digunakan untuk dipresentasikan melalui zoom meeting. Menurut Suryanti bahwa pembelajaran sains harus lebih ditekankan pada pemberian masalah secara kontekstual guna mengembangkan kompetensi peserta didik untuk mengeksplorasi dan memahami lingkungan alam sekitar terutama yang berkaitan dengan pencemaran lingkungan (Siddiq et al., 2020). Setelah proses kegiatan pembelajaran peserta didik mampu menganalisis dan mengevaluasi, selanjutnya akan membantu peserta didik dalam menarik kesimpulan mengenai semua fenomena yang terjadi di lapangan (Susanti, Fina, 2019). Sedangkan pada kelas kontrol tidak diberikan kesempatan untuk menyimpulkan secara presentasi akan tetapi pendidik hanya mengarahkan untuk merangkum materi dari awal sampai akhir pembelajaran.

Berdasarkan hasil tersebut menunjukkan bahwa nilai persentase kelas eksperimen menggunakan model pembelajaran Problem Based Learning mampu membantu kemampuan literasi sains peserta didik menjadi meningkat, yang menggunakan pembelajaran berbasis Blended Learning membuat peserta didik menjadi lebih aktif, melatih kemampuan literasi sains dan menjadikan peserta didik mandiri. Sedangkan pada kelas kontrol menggunakan metode direct instruction proses pembelajarannya peserta didik dalam menyelesaikan masalah masih mendapat arahan dari pendidik yang hanya sebatas dari materi yang sudah diajarkan sehingga kurang melatih kemampuan literasi sains peserta didik. Berdasarkan penelitian yang dilakukan Wayan Suana, hasil instrumen soal kemampuan pemecahan masalah peserta didik pada kelas eksperimen memperoleh kategori sedang pada kelas kontrol memperoleh kategori rendah sehingga dapat disimpulkan bahwa peserta didik kelas eksperimen yang menerapkan 
pembelajaran Blended Learning lebih tinggi dibandingkan peserta didik kelas kontrol yang menerapkan pembelajaran direct instruction (Suana et al., 2019). Sedangkan meningkatnya kemampuan literasi sains peserta didik pada kelas eksperimen disebabkan karena dalam proses pembelajaran menerapkan model pembelajaran Problem Based Learning dan setiap tahapannya menuntut peserta didik mencari sendiri mulai dari perumusan masalah, pemecahan masalah, dan mengumpulkan data untuk pemecahan masalah dan menarik kesimpulan (Briana \& Turnip, 2016).

Pembelajaran pada model Problem Based Learning berbasis Blended Learning, diawali dengan melakukan observasi guna mengetahui kemampuan awal, diperoleh hasil peserta didik belum menguasai kemampuan literasi sains (Banila et al., 2021). Hal tersebut dapat dilihat dari rendahnya nilai setiap indikator kemampuan literasi sains (Mukharomah et al., 2021). Lima indikator kemampuan literasi sains yang meliputi kemampuan memahami fenomena, mengidentifikasi permasalahan, menjelaskan perbedaan, penggunaan bahan-bahan, dan memecahkan permasalahan secara ilmiah ternyata masih banyak peserta didik yang belum menguasainya (Zulfa \& Haryanto, 2021). Nilai setiap indikator pada keterampilan literasi sains masih rendah dan masih dibawah rata-rata. Melalui model pembelajaran Problem Based Learning berbasis Blended Learning, peserta didik akan dilatih guna menguasai kemampuan literasi sains (Ulandari \& Mitarlis, 2021). Berikut dokumentasi KBM pada kelas eksperimen dengan penggunaan model pembelajaran Problem Based Learning berbasis Blended Learning menggunakan aplikasi Zoom meeting, dan Google Classroom.

Terdapat langkah kegiatan model pembelajaran Problem Based Learning berbasis Blended Learning terdiri dari lima tahap (Fadhilatunnisa et al., 2020) adalah sebagai berikut: tahap pertama orientasi pada masalah yang dilakukan peserta didik, dimana pendidik menjelaskan alur dan proses mengevaluasi dalam pembelajaran . Selanjutnya tahap kedua yaitu pendidik menjadi fasilitator untuk peserta didik pada masalah-masalah yang sudah di identifikasi sebelumnya (Naila \& Khasna, 2021).

Tahap ketiga yaitu tahap membimbing saat pengamatan. Pendidik mendorong anak didiknya agar bisa memperoleh informasi, melakukan percobaan, serta memberikan ide pada persoalan yang dihadapi. Tahap ini dapat melatih indikator kemampuan literasi sains yaitu kemampuan menjelaskan fenomena secara ilmiah (Ulandari \& Mitarlis, 2021). Tahap keempat dari model pembelajaran Problem Based Learning berbasis Blended Learning yaitu tahap dimana adanya pengembangan serta menyajikan hasil yang diperoleh, dimana pendidik memfasilitasi peserta didik dalam memecahkan permasalahan sebelumnya, kemudian dikelompokkan berdasarkan kategorinya. Tahap terakhir yaitu tahap menganalisa serta menilai keberlangsungan dalam memecahkan masalah. Pendidik menyuruh kepada peserta didik guna mewujudkan dan meningkatkan aktivitas selama KBM. Tahap ini dapat melatih indikator kemampuan literasi 
sains peserta didik yaitu kemampuan memecahkan permasalahan secara ilmiah (Zulfa \& Haryanto, 2021).

Berdasarkan langkah-langkah model pembelajaran diatas dapat disimpulkan bahwa langkah-langkah pada model pembelajaran tersebut efektif untuk dapat meningkatkan kemampuan literasi sains peserta didik dibandingkan dengan pembelajaran direct instruction. Penerapan model pembelajaran Problem Based Learning berbasis Blended Learning menjadikan peserta didik lebih terarah dalam proses diskusi kelompok, karena peserta didik menjadi terstruktur yang memudahkan dalam menerima ilmu pengetahuan. Jika peserta didik mengikuti tahap-tahap dengan baik dan benar, maka peserta didik bisa memahami dan menyelesaikan setiap persoalan.

\section{KESIMPULAN}

Kesimpulan yang diperoleh dari penelitian yang telah dilakukan yaitu terdapat pengaruh model pembelajaran Problem Based Learning berbasis Blended Learning terhadap kemampuan literasi sains peserta didik. Hasil penelitian pada kemampuan literasi sains di kelas eksperimen kontrol yaitu penelitian pada kelas eksperimen lebih baik dibandingkan penelitian pada kelas kontrol. Terdapat perbedaan rata-rata yang signifikan pada kelas eksperimen dan kelas kontrol. Peneliti berharap untuk peneliti selanjutnya yang ingin mengukur kemampuan literasi sains peserta didik, untuk dapat memilih model pembelajaran yang lebih efektif, efisien dan menyenangkan yang dapat meningkatkan kemampuan literasi sains peserta didik.

\section{REFERENSI}

Adi, W. C., Suwono, H., \& Suarsini, E. (2017). Pengaruh Guided Inquiry - Blended Learning. Jurnal Pendidikan:Teori, Penelitian, Dan Pengembangan, 2(10), 1369-1376.

Adiwiguna, P. S., Dantes, N., \& Gunamantha, I. M. (2019). Pengaruh Model Problem Based Learning (PBL) Berorientasi STEM Terhadap Kemampuan Berpikir Kritis Dan Literasi Sains Siswa Kelas V Sd Di Gugus I Gusti Ketut Pudja. PENDASI: Jurnal Pendidikan Dasar Indonesia, 3(2), 94-103.

Anggraeni. (2019). Pengaruh Blended Learning terhadap Kemampuan Berpikir Kritis Siswa SMA pada Materi Suhu dan Kalor. Jurnal Pendidikan, 4(6), 758-763.

Anggraini, A., \& Syahbrudin, J. (2021). Implementasi Blended Learning Berbasis Problem Solving Chat Untuk Meningkatkan Keterampilan Pemecahan Masalah. Eduka: Jurnal Pendidikan, Hukum, Dan Bisnis, 6(1), 25-32.

Aulia, L. N., Susilo, S., \& Subali, B. (2019). Upaya Peningkatan Kemandirian Belajar Siswa Dengan Model Problem-Based Learning Berbantuan Media Edmodo. Jurnal Inovasi Pendidikan IPA, 5(1), 69-78. https://doi.org/10.21831/jipi.v5i1.18707

Bahrul Hayat, Suhendra Yusuf. (2015). Benchmark Internasional Mutu Pendidikan.

Bahrul Hayat, S. Y. (2006). Bechmark Internasional Mutu Pendidikan.

Banila, L., Lestari, H., \& Siskandar, R. (2021). Penerapan Blended Learning Dengan Pendekatan STEM Untuk Meningkatkan Kemampuan Literasi Sains Siswa Pada Pembelajaran Biologi Di Masa Pandemi. Journal of Biology Learning, 3(1), 25-33.

Briana, J., \& Turnip, B. M. (2016). Pengaruh Model Problem Based Learning Terhadap Kemampuan Pemecahan Masalah Siswa SMA. INPAFI (Inovasi Pembelajaran Fisika), 4(3), 
87-94. https://doi.org/10.24114/inpafi.v4i3.5597

Crawford, Renee. (2017). Pembelajaran Campuran Dan Pengajaran Tim: Mengadaptasi Pedagogi Dalam Menanggapi Perubahan Lingkungan Tersier Digital. Teknologi Pendidikan Australia, 33, 2.

Fadhilatunnisa, D., Rosidah, \& Fakhri, M. M. (2020). The Effectiveness of The Blended Learning Model on The Students' Critical Thinking Skills And Learning Motivation In Accounting Department. Lentera Pendidikan, 23(2), 194-208.

Fuadi, Husnul. (2020). Analisis Faktor Penyebab Rendahnya Kemampuan Literasi Sains Peserta Didik. Ilmiah Profesi Pendidikan, 5(2).

Haerani, S. A. S., Setiadi, D., \& Rasmi, D. A. C. (2020). Pengaruh Model Inkuiri Bebas Terhadap Kemampuan Literasi Sains. Jurnal Pijar Mipa, 15(2), 140. https://doi.org/10.29303/jpm.v15i2.1682

Hamka, D., \& Effendi, N. (2019). Pengembangan Media Pembelajaran Blended Learning Berbasis Edmodo Pada Mata Kuliah Fisika Dasar di Program Studi Pendidikan IPA. 2(1), 19-33.

Ismail, I., Permanasari, A., \& Setiawan, W. (2016). Efektivitas Virtual Lab Berbasis STEM dalam Meningkatkan Literasi Sains Siswa Dengan Perbedaan Gender. Jurnal Inovasi Pendidikan IPA, 2(2), 190. https://doi.org/10.21831/jipi.v2i2.8570

Lestari, H. (2020). Literasi Sains Siswa Melalui Penerapan Model Pembelajaran Blended Learning Dengan Blog. 4(2), 597-604.

Meylani, V., Kuswarini, P., \& Nurhidayah. (2018). Pengaruh Model Problem Based Learning Dibantu Fishbone Diagram Terhadap Keterampilan Proses Sains Biologi Peserta Didik di SMA Negeri 1 Karangnunggal. EKSAKTA: Jurnal Penelitian Dan Pembelajaran MIPA, 3(2), $11-18$.

Mukharomah, F., Wiyanto, \& Putra, N. M. D. (2021). Analisis Kemampuan Literasi Sains Fisika Siswa Sma Pada Materi Kinematika Gerak Lurus Di Masa Pandemi Covid-19. JoTaLP: Journal of Teaching and Learning Physics, 1(6), 11-21.

Naila, I., \& Khasna, F. T. (2021). Pengaruh Pembelajaran Daring Terhadap Kemampuan Literasi Sains Calon Guru Sekolah Dasar: Sebuah Studi Pendahuluan. Jurnal Kajian Pendidikan Dan Hasil Penelitian, 7(1), 42-47.

Nanclares, Hernandez Nuria. (2016). Kepuasan Siswa Dengan Desain Pembelajaran Terpadu: Potensi Flipped Classroom. Media Interaktif Dalam Pendidikan, 1(1), 4.

Nugraha, A. J., Suyitno, H., \& Susilaningsih, E. (2017). Analisis Kemampuan Berpikir Kritis Ditinjau dari Keterampilan Proses Sains dan Motivasi Belajar melalui Model PBL. Journal of Primary Education, 6(1), 35-43.

Rusdi, A., Sipahutar, H., \& Syarifuddin, S. (2017). Hubungan Kemampuan Berpikir Kreatif dan Sikap Terhadap Sains Dengan Literasi Sains Pada Siswa Kelas XI IPA MAN. Jurnal Pendidikan Biologi, 7(1), 72-80. https://doi.org/10.24114/jpb.v7i1.9983

Siddiq, M. N., Supriatno, B., \& Saefudin, S. (2020). Pengaruh Penerapan Problem Based Learning Terhadap Literasi Lingkungan Siswa SMP Pada Materi Pencemaran Lingkungan. Assimilation: Indonesian Journal of Biology Education, 3(1), 18-24. https://doi.org/10.17509/aijbe.v3i1.23369

Suana, W., Raviany, M., \& Sesunan, F. (2019). Blended Learning Berbantuan Whatsapp: Pengaruhnya Terhadap Kemampuan Berpikir Kritis Dan Kemampuan Pemecahan Masalah. Gravity: Jurnal Ilmiah Penelitian Dan Pembelajaran Fisika, 5(2), 37-45. https://doi.org/10.30870/gravity.v5i2.4990

Susanti, Fina. (2019). 'Pengaruh Pendekatan Pembelajaran Science, Technology, Engineering And Mathematics (Stem) Dengan Metode Brainstorming Terhadap Kemampuan Berpikir Kritis Dan Berpikir Kreatif Peserta Didik Pad Pembelajaran Fisika. Skripsi Lampung: Universitas Islam Negeri Raden Intan Lampung.

Taofiq, M., Setiadi, D., \& Hadiprayitno, G. (2018). Analisis Implementasi Model Pembelajaran Inkuiri dan Problem Based Learning Terhadap Kemampuan Literasi Sains Biologi Ditinjau dari Kemampuan Akademik yang Berbeda di SMAN 1 Kayanga. Prosiding Seminar Nasional Pendidikan Biologi, 2007, 549-555.

Taqiyyah, S. A., Subali, B., \& Handayani, L. (2017). Implementasi Bahan Ajar Sains Berbahasa 
Inggris Berbasis Metakognitif Untuk Meningkatkan Kemampuan Pemecahan Masalah Siswa SMP. Jurnal Inovasi Pendidikan IPA, 3(2), 224. https://doi.org/10.21831/jipi.v3i2.14859

Triyanto, S. A., Susilo, H., \& Rohman, F. (2016). Penerapan Blended-Problem Based Learning dalam Pembelajaran Biologi. Jurnal Pendidikan, 1(1), 1252-1260.

Ulandari, A., \& Mitarlis. (2021). Pengembangan Lembar Kerja Peserta Didik (LKPD) Berwawasan Green Chemistry Untuk Meningkatkan Kemampuan Literasi Sains Pada Materi Asam Basa. Jurnal Inovasi Pendidikan Kimia, 15(1), 2764-2777.

Wilujeng, M. F. S. dan insih. (2016). Pengembangan SSP Zat dan Energi Berbasis Keunggulan Lokal untuk Meningkatkan Literasi Sains dan Kepedulian Lingkungan Developing of Essence and Energy SSP Based on Local Wisdom to Improve Literacy Science and Environmental Care of Students of MTs. Jurnal Inovasi Pendidikan IPA, 2(1), 66-75.

Wulandari, N., \& Sholihin, H. (2015). Penerapan Model Problem Based Learning (PBL) Pada Pembelajaran IPA Terpadu Untuk Meningkatkan Aspek Sikap Literasi Sains Siswa SMP. Prosiding Simposium Nasional Inovasi Dan Pembelajaran Sains 2015, 2015(Snips), 437-440.

Zulfa, L. N., \& Haryanto. (2021). Pengaruh Media Macromedia Flash Terhadap Literasi Sains dan Sikap Demokratis Mahasiswa. Jurnal Pendidikan Sains Indonesia (Indonesian Journal of Science Education), 9(1), 52-64. https://doi.org/10.24815/jpsi.v9i1.18266 